\title{
The analysis on the cause of material waste on the irrigation project in Aceh Besar district
}

\author{
Hafnidar A. Rani* \\ Civil Engineering Department, Engineering Faculty, University of Muhammadiyah Aceh, Banda Aceh, Indonesia
}

\section{(C2017 ACCENTS}

\begin{abstract}
The material as one component of cost estimations also plays important role in supporting the success of one project. The material procurement can absorb so high cost from the project total cost. Therefor the use of the material is attempt as minimum as possible to avoid material waste produced. This study aimed to find out the dominant factor on the cause of material waste on the irrigation project, and to analyze the relationship and the influence between material waste factors and material waste indicators on irrigation project in Aceh Besar district. This study used questionnaire distributed to irrigation contractors, with the qualification of the companies are ranging from $\mathrm{K} 1, \mathrm{~K} 2, \mathrm{~K} 3, \mathrm{M1}$, and $\mathrm{M} 2$ and located in Aceh Besar district since 2010 to 2015. The population obtained is 209 contractors; by using Slovin equation obtained that the study samples are 68 contractors. The result study showed that the dominant factor causes the material waste on the irrigation project in Aceh Besar district is material procurement factor. The relationship between material waste factors and material waste indicators on irrigation project in Aceh Besar district which consists of waste factor, other factor, material procurement factor, material handling factor have high relationship partially with the correlation

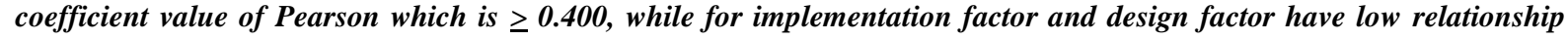
partially with the correlation coefficient value of Pearson which is $\leq 0.400$. The influence between material waste factors and material waste indicators on irrigation project in Aceh Besar district which the most affecting is the material procurement factor and the waste factor. It means that if material procurement factor, material handling factor and waste factor increase will affect material waste indicator on the irrigation project in Aceh Besar district will improve.
\end{abstract}

\section{Keywords}

Material, Material waste, Irrigation, Aceh Besar district.

\section{Introduction}

The construction project is long process, there are many problems and constrains faced in the implementing period. The material becomes one of the factors which playing the important role in supporting the success of one project. In the implementing project period, the material use in the field cannot be avoided from the error and careless situation, which commonly known as material waste, which often arised and difficult to avoid. The material waste cannot be neglected because it can disturb the implementation of the overall construction. This condition will require larger storage place in the project area which sometimes is limited, so we need to think the serious handling process to overcome this problem. From the handling process of material waste, we can separate among reuse material, recycle material, salvage material and disposal material.

*Author for correspondence

53
Many factors can cause material waste, so it is required the better understanding about the concept of the waste and the ability to identify the waste types and the causing factors. If the waste factors can be identified, so the waste which commonly occurred in irrigation construction project implementation can be minimized.

In the irrigation project implementation especially in Aceh Besar district, construction actors still consider that material waste become natural matter found in one project, so that the effort to overcome this problem sometime neglected. Material waste which has not been identified will affect that the contractor does not know how the loss raised because of material waste found in the project location. The excess loss can affect the reduced profit received by the contractor. Based on this problem, we require carrying out the efforts to analyze the causing factors which causing the waste on the irrigation project in Aceh Besar district, so we can overcome this problem. 
Based on the background explained, it is formulated the problem of this study which is what the most dominant factor causing material waste on irrigation project in Aceh Besar district is, and how the relationship and the influence between material waste factors and material waste indicators on Irrigation project in Aceh Besar district. The objective of this study is to analyze the most dominant factor causing material waste on irrigation project in Aceh Besar district and analyze the relationship and the influence between material waste factors and material waste indicators on Irrigation project in Aceh Besar district.

\section{Literature study}

\subsection{Material}

According to [1], material is one of the important aspects in the construction project. The material has high percentage as much as $50-70 \%$ of the total project cost. It shows that construction material needs good management in order to make the material required can be obtained in the appropriate quantity, quality and period.

Mentioned that material required in the construction project can be divided into two parts, they are such mentioned below [2]:

1. Consumable material; the material in which in the end of the construction will be the part of the building physical structure, such as cement, sand, course, brick, the reinforced steel, and others.

2. Non consumable material; the material which can support the construction process, and not become the part of building physical structure after the project finished, such as scaffolding, formwork, whilst retaining walls, and others.

\subsection{Material waste}

Stated that waste material produced from the construction project is the material that cannot be used as the waste of the construction process, repairment or renovation and because the error or accident which cause the material cannot be directly used in that place without any other treatment[3].

\subsection{Material waste type}

Mentioned that waste material produced during the construction implementation can be categorized into two parts [4]:

1. Demolition waste; waste derived from the demolition material of the renovation process or old building demolition.

2. Constructive waste; waste derived from construction process or renovation of, personal building, commercial building and other structures. The waste consists of cement, brick, plaster, wood, shingles, plumbing and electrical components. Construction waste can be categorised into two categories based on the type such mentioned below.

a. Direct waste; waste material produced in the project because it is damaged, lost and not able to be used anymore.

b. Indirect waste; waste material produced from the project because the material used volume exceeds the design volume, so there is no physical waste material in the field and affect the cost hidden

\subsection{The factor causing the material waste}

Mentioned that the sources causing construction material waste can be categorised into six categories, they are mentioned below [5].

1. Design factor

2. Material pprocurement factor

3. Material handling factor

4. Implementation factor

5. Residual factor

6. Other factor

Mentioned that the causing of construction material waste consists of four aspects, they are such below [6].

1. Design aspect

2. Procurement aspect

3. Material hhandling aspect

4. Implementation aspect

\subsection{Material waste indicator}

It is stated that material waste indicator or construction waste can be divided into the below [7].

1. Material cut either contaminated or not contaminated;

2. Construction waste, consisting of all material of building construction, renovation, or demolishing (including concrete, wood, plastic, paper, metal, and others);

3. Construction debris; and

4. Building material production, such as cement, concrete, reinforced steel, wood, and others.

\section{Research methodology}

\subsection{Object and location}

Study object is the factors causing material waste in the irrigation project. This study was conducted in Aceh Besar district, which aimed to the constructors in irrigation sector and SI001 sub sector, starting from small qualification $\left(\mathrm{K}_{1}, \mathrm{~K}_{2}, \mathrm{~K}_{3}\right)$ to the intermediate qualification $\left(\mathrm{M}_{1}, \mathrm{M}_{2}\right)$ located in Aceh Besar district. 


\subsection{Data resources}

Data used in this study is primary and secondary data. The primary data used is questionnaire. While the secondary data used is the map of Aceh Province, map of Aceh Besar district and the list of contractor companies which taking irrigation sector and registered in the association named Construction Service Development Institution of Aceh Province in 2016.

\subsection{Population and sample}

On Construction Service Development Institution data in 2016, there are 209 contractor which registered in irrigation sector starting from small qualification $\left(\mathrm{K}_{1}, \mathrm{~K}_{2}, \mathrm{~K}_{3}\right)$ to the intermediate qualification $\left(\mathrm{M}_{1}, \mathrm{M}_{2}\right)$ located in Aceh Besar district. The samples obtained in this study are 68 contractors.

The sampling technique used in this study is proportionate stratified random sampling using the current proportion. This proportion is based on the construction which has the experiences in handling irrigation project in Aceh Besar district since 2010 2015.

\subsection{Research variable}

The research variable is shown in Figure 1 below.

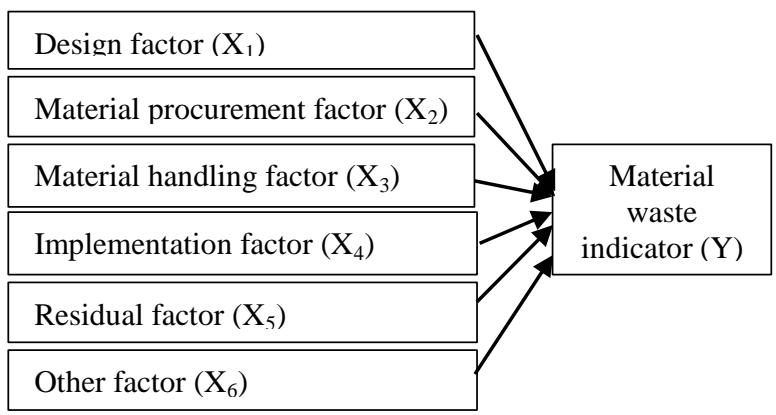

Figure 1 Research variable

\section{Result and discussion}

\subsection{Respondent characteristics}

Based on questionnaire distributed to 68 respondent in which the irrigation sector constructors, showed that small amount of the respondents are $31-40$ years old which total are 35 respondents $(51.47 \%)$, small amount of the respondents are 20-30 years old which total are 18 respondents $(26.47 \%)$, some are 41-50 years old which total are 11 respondents $(16.18 \%)$, and the respondents with more than 50 years old which is 4 respondents (5.88\%). All respondents are men. There are 47 respondents $(69.12 \%)$ who are bachelor degree, there are 9 respondents (13.24\%) who are diploma degree and there are 6 respondents $(8.82 \%)$ of each who are senior high school degree and master degree.

There are 24 respondents $(35.29 \%)$ as the field officer, there are 14 respondents $(20.59 \%)$ as director and site manager, there are 10 respondents $(14.71 \%)$ as quantity engineer, and there are only 6 respondents $(8.82 \%)$ as quality engineer.

There are 34 respondents $(50.00 \%)$ whose working experience period is $6-8$ years, There are 19 respondents $(27.94 \%)$ whose working experience period is $>8$, There are 13 respondents $(19.12 \%)$ whose working experience period is $3-5$ years, and There are 2 respondents $(2.94 \%)$ whose working experience period is $0-2$ years.

Based on the company qualification, $\mathrm{K} 1$ is 53 respondents (77.94\%), K2 is 6 respondents $(8.82 \%)$, $\mathrm{K} 3$ and M1 are each 4 respondents (5.88\%), and M2 is 1 respondent $(11.34 \%)$. The respondents' distribution based on the company qualification can be shown clearly in Figure 2.

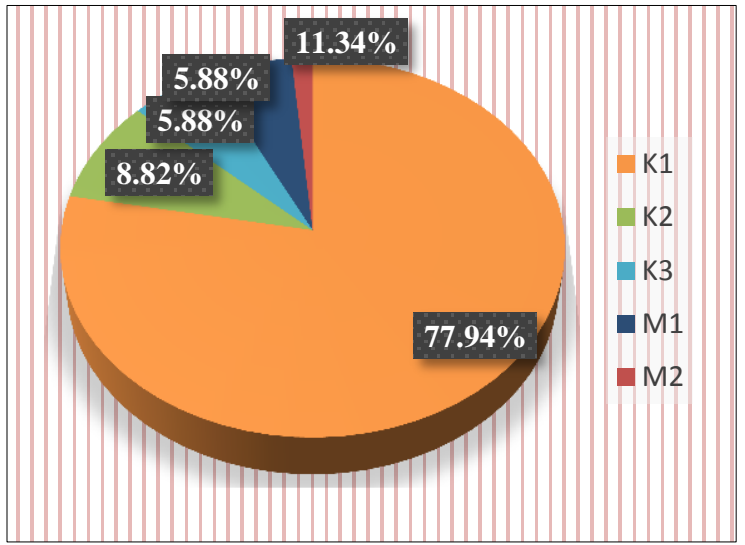

Figure 2 Percentage of qualifying characteristics of the company

\subsection{Causing factors of material waste}

The mean table of each material waste factor completed with the deviation standard and the ranking can be shown in the Table 1 .

Table 1 Mean value of the material waste factors causes

\begin{tabular}{llcll}
\hline NO. & Variable & Mean & $\begin{array}{l}\text { Deviasi } \\
\text { Standard }\end{array}$ & Ratings \\
\hline X1 & Design factor & 4.431 & 5.195 & 2 \\
X2 & $\begin{array}{l}\text { Material } \\
\text { procurement } \\
\text { factor }\end{array}$ & 4.459 & & 1 \\
X3 & Material & 3.641 & \\
\cline { 3 - 4 } & & & 6.177 & 5 \\
\hline
\end{tabular}




\begin{tabular}{lllll}
\hline NO. & Variable & Mean & $\begin{array}{l}\text { Deviasi } \\
\text { Standard }\end{array}$ & Ratings \\
\hline X4 & $\begin{array}{l}\text { handling factor } \\
\text { Implementation } \\
\text { factor }\end{array}$ & 4.283 & 5.332 & 4 \\
X5 & Residual factor & 4.185 & 3.822 & 6 \\
X6 & Other factor & 4.387 & 2.435 & 3 \\
\hline
\end{tabular}

Based on the above table, the highest mean obtained is material procurement factor with the mean is 4.459. It showed that based on the constructors' perception, the most dominant factor causing material waste in irrigation project in Aceh Besar district is material procurement factor. The material procurement factor consists of the indicators such as the mistake in the order both more or less and others, the purchasing cannot be done in the small amount, material purchasing is not suitable with the specification, the supplier sent the material which is not suitable with the qualification and less good packing condition causing the damage in the transportation.

The research conducted by [8] showed that based on frequency index calculation result obtained that the indicator of the most dominant factor causing material waste in irrigation rehabilitation project in Aceh Province the is excess demand or shortage demand of material because of quantity design mistake.

4.3 The relationship between material waste factors and material waste indicators

The relationship between material waste factors and material waste indicators has been analysed using simple correlation analysis. Based on Pearson correlation coefficient, showed that material waste factors simultantly have the high relationship to waste material indicators in irrigation project in Aceh Besar district, with the correlation coefficient is 0.799 .

\subsection{The effect of material waste factor to material waste indicator}

Totally, multiple linear regression analysis showed that from all the factors which have regression coefficient value, the highest values are obtained material procurement factor, material handling factor and waste factor. It means that the most dominant factors of the material waste affecting to the material waste indicator in irrigation project in Aceh Besar district found are material procurement factor, material handling factor and waste factor. So if material procurement factor, material handling factor and waste factor are increased, material waste indicators in irrigation project in Aceh Besar district will also increase.

F test showed that material waste factors have significant effects to waste material indicators in irrigation project in Aceh Besar District simultantly, with the value of $F_{\text {counted }} \geq F_{\text {table }}$ which is 17,948 $\geq$ 2.36 and signification value is $0.000 \leq 0.05$.

Determination coefficient showed that material waste factors give simultantly effects which is $60.3 \%$ to material waste indicator in irrigation project in Aceh Besar district, while the rest which is $39.7 \%$ is affected by other factors which is not observed in this study.

\section{Conclusion and future work}

Material waste is the material which is excessive or has finished to be used, including reused material, recycling material or the material which can be returned to the supplier, and can be disposed to other place which can be used by other people.

The construction material waste will keep increasing in line with construction development implemented. In addition to effect the project cost, it will also raise new problem which can disturb project environmental and surrounding area. The controlling of material waste quantity can be carried out by several methods; recycling the material become the useful items; demolishing the material by burning; and finding out the method to decrease material waste produced.

\section{Conflicts of interest}

The authors have no conflicts of interest to declare.

\section{References}

[1] Ervianto WI. Teori aplikasi manajemen proyek konstruksi. Andi Yogyakarta. 2004.

[2] Gavilan RM, Bernold LE. Source evaluation of solid waste in building construction. Journal of Construction Engineering and Management. 1994; 120(3):536-52.

[3] Prairie Village KS. Characterization of buildingrelated construction and demolition debris in the United States.

[4] Tchobanoglous G, Theisen H, Vigil S. Integrated solid waste management: engineering principles and management issues. McGraw-Hill Science/ Engineering/ Math; 1993.

[5] Bossink BA, Brouwers HJ. Construction waste: quantification and source evaluation. Journal of Construction Engineering and Management. 1996; 122(1):55-60. 
[6] Saya T. Penyebab Sisa Material Konstruksi pada Pembangunan Ruko di Banda Aceh. Jurnal Teknik Sipil. 2010; 1(9): 61-7.

[7] Kartam N, Al-Mutairi N, Al-Ghusain I, Al-Humoud J. Environmental management of construction and demolition waste in Kuwait. Waste Management. 2004; 24(10):1049-59.

[8] Muktian, Yulianur A, Fatimah E. studi faktor-faktor utama penyebab pemborosan material (material waste) pada proyek rehabilitasi jaringan irigasi provinsi Aceh. Jurnal Teknik Sipil. 2013; 2(2): 15-21.

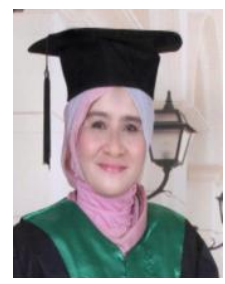

Hafnidar A. Rani was born in Aceh on March $14^{\text {th }}$, 1970. She graduated her Bachelor Degree from Syiah Kuala University as a Civil Engineer in 1995. Then she continued her Master Program in Management Magister of Syiah Kuala University and graduated in 2000. She commenced her doctoral program in Construction Project Management of Universiti Utara Malaysia in 2006 and graduated the program in 2012. After receiving her bachelor degree, she became the Civil Engineering lecturer and teaching in Muhammadiyah Aceh University. Her subjects are Construction Management, Project Management, Research Methodology, Statistic and Probability, Engineering Economic, and Value Engineering. Dr. Hafnidar has been in her current position as the Dean of Engineering Faculty in Muhammadiyah Aceh University since 2016. She is actively conducting the researches especially in the last 5 years and also participating in seminar and conferences both national and international. In 2012, she also conducted the research for the community dedication which tittle was Techniques for Earthquake Resistant House Construction in Coastal Areas. She is also active as the keynote speaker in the seminar both national and international and as the reviewer of some Civil Engineering Journals. Her newest guideline book written is Construction Project Management produced in the beginning of 2016.

Email: nidarrani@yahoo.com 